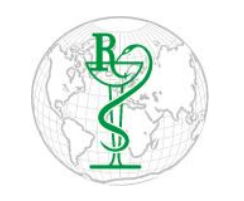

INDO GLOBAL JOURNAL OF

PHARMACEUTICAL SCIENCES

ISSN 2249- 1023

\title{
Pharmacology and Phytochemistry of Artocarpus Family: A Review
}

\author{
Krupa S., C. S. Karigar *, K. R. Siddalinga Murthy \\ Department of Biochemistry, Bangalore University, Jnanabharathi, Bangalore 560056, India
}

Address for Correspondence: C.S. Karigar, karigar@bub.ernet.in

\begin{abstract}
Received:
05.07.2019

Accepted:

03.02.2020

Published:

24.11.2020

Keywords

Moraceae;

Artocarpus;

Secondary

metabolites;

Phytochemistry;

Pharmacology..
\end{abstract}

\begin{abstract}
The genus Artocarpus, belongs to family Moraceae and consists of more than 50 species. The species are either evergreen or deciduous trees are found in India, Southern China, Malaysia and the Solomon Islands. Fruits of Artocarpus species are edible and used as traditional medicines. All the parts of the tree such as leaves, fruits, seeds, roots and barks are of great Ayurvedic and Unani medicinal importance. The extracts have been used traditionally in the treatment of diabetes, diarrhea, dermatitis, malarial fever, asthma, tapeworm infection, anaemia, wound healing, anti - syphilitic, vermifuge activity, to induce lactation in women and domesticated animals and aphrodisiac properties. Latex obtained from the family promotes healing of abscesses, snakebite and glandular swellings. Our study aims at comprising the available information on the phytochemicals and pharmacological studies with reference to Artocarpus. The species of Artocarpus are highly rich in secondary metabolites like flavanoids, stilbenoids, arylbenzofurans and a lectin (Jacalin) which makes them a promising source of phytomedicine. This review focuses on therapeutic substances from the Artocarpus species, their extraction, characterization, nano-synthesis, assessment of their roles in traditional and modern medicine. (c) 2020 iGlobal Research and Publishing Foundation. All rights reserved.
\end{abstract}

Cite this article as: Krupa, S.; Karigar, C.S.; Murthy, K.R.S. Pharmacology and phytochemistry of Artocarpus family: a review. Indo Global J. Pharm. Sci., 2020; 10(3): 48-55. DOI: http://doi.org/10.35652/IGJPS.2020.10306.

\section{INTRODUCTION}

Moraceae is a widespread family often called the mulberry or fig family comprised in the Angiosperms or flowering plants. Moraceae members are monoecious or dioecious with 37 to 43 genera and 1100 to 1400 species including important group such as Artocarpus, Morus, Ficus which are widespread in tropical and subtropical areas. Moraceae constitutes trees, shrubs, vines, or rarely herbs, with milky or watery latex and spiny fruit cover. Stipules are present and are caducous. The leaves appear alternate and possess well-defined petioles. The leaf blades are simple with cystoliths, with entire or palmately lobed margins, venation is pinnate and palmate. Axiliary inflorescences are observed while the flowers are unisexual and small. Calyx lobes may vary 1 or $2-4$ or 8 , are free or connate, imbricate or valvate. Corolla is absent. The male flowers except in Artocarpus, are straight or inflexed in bud with 1-or 2-loculed, crescent-shaped to top-shaped anthers and rudimentary sterile pistil. Female flowers possess four calyx lobes with superior, semi-inferior, or inferior, 1(or 2)-loculed ovary, anatropous or campylotropous ovules and stigmas are usually filiform. Fruits are drupe enveloped by an enlarged calyx and/or immersed in a fleshy receptacle, often joined into a syncarp. Seeds are solitary with or without endosperm [1]. The flowers are unisexual and minute, and are densely aggregated [2].Economically, the most important species of Morus and Maclura are associated with the production of silk. Some species among Broussonetia, Maclura and Morus are important for paper making, some species of Artocarpus, Ficus, and Morus have edible fruit and some species of Artocarpus and Broussonetia are used for furniture or timber. This review is an effort to compile all major information on the commonly available Artocarpus species, its phytochemical as well as pharmacological profile.

Artocarpus is one of the genera belonging to the family Moraceae. It consists of more than 50 species distributed in the tropical and subtropical regions of Asia. It is native to Western Ghats of India, Malaysia and also found in Central and Eastern Africa, South-Eastern Asia. They are monoecious, evergreen or deciduous trees with edible fruits and white latex. 
Indo Global Journal of Pharmaceutical Sciences, 2020; 10(3): 48-55

Leaves of this genus are spirally arranged or distichous and are simple, pinnatified or pinnate, coracious, glaborous to pubescent, leathery and margin entire. Inflorescences are seen on the main branches which are unisexual, capitates and many flowered. Male flowers are surrounded by peltate to calvate interfloral bracts with globose to oblong biloculed anthers. Female flowers are with tubular perianth, basally thin walled enclosing ovary which is unilocular and apically thick walled and the perianths are partially or completely fixed one to another to form syncarp. Flowers and bracts fuse at the tip to form syncarp which gives an aggregate fruit which is fleshy throughout. Seeds are with fleshy cotyledons. It grows in a soil which is well drained but moist, with a $\mathrm{pH}$ of 4.3 to 8.0 and with medium soil fertility. The optimum temperature is $19^{\circ} \mathrm{C}$ to $29^{\circ} \mathrm{C}$, altitude at approximately 1600 meters above sea level and the annual rain fall between 1000 and $2400 \mathrm{~mm}$ [3]. Some of the important species belonging to this genus are $A$. communis, A. altilis, A. heterophyllus, A. hirsutus and A. lakoocha.

\section{PHYTOCHEMISTRY AND PHARMACOLOGICAL PROPERTIES}

\section{Artocarpus heterophyllus Lam}

Artocarpus heterophyllus Lam, also called as Jackfruit or Ceylon Jack tree is an integral part of Indian diet. It is very popular in Bangladesh and considered as their national fruit. The term jackfruit is derived from the Portughese term Jaca and Malayalam an Indian regional language chakka [4]. This fruit is considered as "poor man's food" as it is inexpensive and easily available in large quantity during summer when food is scarce. The presence of flavonoids, alkaloids, saponins, tannins, terpenoids, glycosides, xanthoproteins and phenols contribute to its medicinal properties. They possess antibacterial, antioxidant, anti-diabetic, anti-inflammatory, anti-diuretic, immunomodulatory properties useful in the treatment of fever, skin diseases, convulsions, constipation, ophthalmic disorders, and snake bite. The leaves and stem barks are used to treat anemia, asthma, dermatitis, diarrhea, and cough. Leaves are used to increase lactation in women and animals. Many value added products like; instant soups, bakery products, baby foods, candy and ice cream are manufactured using wheat flour added with jackfruit seed powder [5]. Fruit contains sugars like glucose, fructose, sucrose contributing for total carbohydrate of $18.9 \mathrm{~g}$ protein $(1.9 \mathrm{~g})$, fat $(0.1 \mathrm{~g})$, moisture $(77 \%)$ and fiber $(1.1 \mathrm{~g})$, minerals of $(0.8 \mathrm{~g})$, where calcium (20mg), phosphorous $(30 \mathrm{mg})$, iron (500mg), vitamin A (540IU), thiamin (30mg) and calorific value of 84 are available [6].

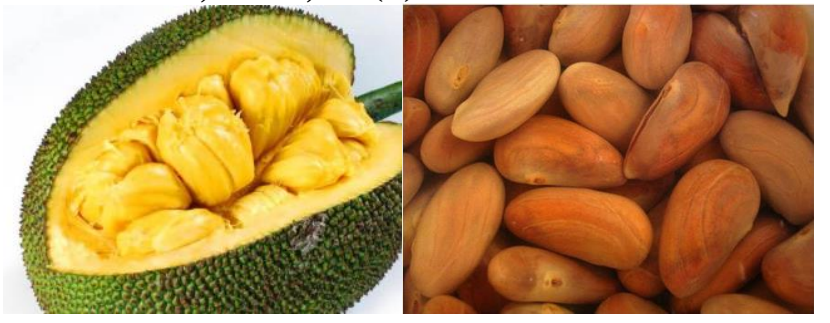

Figure 1. Fruit of A. heterophyllus

(https://www.newsoftown.com/)

\begin{tabular}{|l|l|}
\hline \multicolumn{1}{|c|}{ Indices } & \multicolumn{1}{c|}{ Values } \\
\hline Water Absorption Capacity (\%) & $25.00 \pm 1.67$ \\
\hline Fat Absorption Capacity (\%) & $17.00 \pm 1.37$ \\
\hline Bulk density (\%) & $0.80 \pm 0.02$ \\
\hline Foaming Capacity (\%) & $25.34 \pm 0.02$ \\
\hline Foam stability (\%) & $33.00 \pm 0.01$ \\
\hline Swelling Power (g/g) & $4.77 \pm 0.01$ \\
\hline
\end{tabular}

Table 1. Physio chemical properties of $A$. heterophyllus seed [Ocloo et.al., 2010].

The total fruit weight comprises of seeds $(8-15 \%)$ which are the storage source of polysaccharides like guar galactomannans, glucomannans, xyloglucans and galactomannans, phenols, proteins, carbohydrates. The oil content of this plant is $11.39 \%$ [7].The brown spermoderm around the endosperm is a rich source of starch and proteins $[8,9]$.The qualitative analysis of phytochemicals in the seeds of A. heterophyllus showed the presence of phenolics. Quantitative analysis of total phenols and total flavonoids of A. heterophyllus seed extracts was conducted using Gallic Acid Equivalents (GAE) and Quercetin Equivalents (QE). A.heterophyllus seeds and the seed oils are good antibacterial agents towards Staphylococcus aureus, Escherichia coli, Klebsiella pneumoniae, Pseudomonas aeruginosa. The parts of jackfruit have shown the antioxidant activity and phenolic content. The seed extract showed higher antioxidant (DPPH scavenging) activity with an IC50 of $410 \mu \mathrm{g} / \mathrm{ml}$. Scavenging of $\mathrm{H} 2 \mathrm{O} 2$ and its percentage inhibition by methanolic extracts of seeds of A. heterophyllus were studied. The extracts exhibited an IC50 value of $32.51 \mu \mathrm{g} / \mathrm{ml}$ [10]. The seed oils of jackfruit show remarkable antioxidant activity. Such properties can be explored for the economic, nutritional and health applications. Gas chromatographic analysis of the seed oils revealed high amount of unsaturated fatty acids like methyl dodecanoate, methyl decanoate and tetradecane. Green synthesis of nanoparticles from aqueous solution of silver nitrate using A. heterophyllus seed powder as a reducing agent explored good antimicrobial activity against Gram positive and Gram negative bacteria. Jacalin present in the seeds of jackfruit is of potential use in nano-medicine. Jackfruit seeds are a very good source of lectins called Jacalin [11]. Jacalin is a tetrameric two chain lectin with a molecular mass of $65 \mathrm{kD}$ comprising a heavy $\alpha$-chain of 133 amino acid residues and a light $\beta$-chain 
Indo Global Journal of Pharmaceutical Sciences, 2020; 10(3): 48-55

of 20-21 aminoacid residues. Jacalin contributes to more than $50 \%$ of the total protein present in the seed.

\begin{tabular}{|c|c|}
\hline Phytoconstituents & $\begin{array}{c}\text { Plant } \\
\text { part }\end{array}$ \\
\hline Carbohydrates- starch, sugar, dietary fiber & $\begin{array}{l}\text { Fruit, } \\
\text { Seed }\end{array}$ \\
\hline Minerals- Calcium, Magnesium, Phosphorous, Sodium, Iron & $\begin{array}{l}\text { Fruit, } \\
\text { Seed }\end{array}$ \\
\hline $\begin{array}{l}\text { Fatty Acids- Capric, Myristic, Lauric,Palmitic, Oleic, } \\
\text { Stearic }\end{array}$ & Fruit \\
\hline Organic acids- Malic acid, citric acid & Fruit \\
\hline $\begin{array}{l}\text { Carotenoids- 2- carotene, 1- carotene,1- zeacarotene, 2- } \\
\text { zeacarotene, diacrboxylic carotenoids }\end{array}$ & $\begin{array}{l}\text { Fruit, } \\
\text { Seed }\end{array}$ \\
\hline $\begin{array}{l}\text { Flavonoids- Artocarpine, Artocarpetin, Artonins A, Morin, } \\
\text { Dihydromorin, Artocarpanone, Artocarpesin }\end{array}$ & Fruit \\
\hline Lectin- Jacalin & Seed \\
\hline $\begin{array}{l}\text { Volatiles- Isopentylisovalerate, Butyl isovalerate, Butyl } \\
\text { acetate }\end{array}$ & $\begin{array}{l}\text { Seed } \\
\text {,Fruit }\end{array}$ \\
\hline Tannins & $\begin{array}{l}\text { Stem, } \\
\text { Leaf }\end{array}$ \\
\hline Vitamins- Vitamin A, Thiamine, Riboflavin, V & Fruit \\
\hline
\end{tabular}

Table 2. Phytoconstituents of $A$. heterophyllus [Tejpal et.al., 2016]

The anti-inflammatory activity stabilizes lysosomal membrane and inhibits the inflammatory process by restricting the release of lysosomal enzymes preventing the damage to surrounding tissues. The red cell membrane stabilizing activity on seeds and the highest inhibition of heat induced hemolysis in the methanolic extracts were studied.

\begin{tabular}{|l|l|l|l|}
\hline $\begin{array}{l}\text { Pharmacologi } \\
\text { cal activities }\end{array}$ & \multicolumn{1}{|c|}{ Plant Parts } & \multicolumn{1}{|c|}{ Extracts } & $\begin{array}{c}\text { Phytocons } \\
\text { tituent }\end{array}$ \\
\hline $\begin{array}{l}\text { Anti } \\
\text { infective }\end{array}$ & \multicolumn{3}{|l|}{} \\
\hline Anti - fungal & Leaf, Seed & $\begin{array}{l}\text { Alcoholic } \\
\text { extract }\end{array}$ & Chalcone \\
\hline Anti - viral & Seed & $\begin{array}{l}\text { Alcoholic } \\
\text { extract }\end{array}$ & $\begin{array}{l}\text { Oxyresver } \\
\text { atrol }\end{array}$ \\
\hline Anti - fungal & $\begin{array}{l}\text { Bark of stem and } \\
\text { fruit leaves and }\end{array}$ & $\begin{array}{l}\text { Alcoholic } \\
\text { extract }\end{array}$ & $\begin{array}{l}\text { Isoprenyl } \\
\text { flavones }\end{array}$ \\
\hline Anti - cancer & Wood & $\begin{array}{l}\text { Alcoholic } \\
\text { extract }\end{array}$ & $\begin{array}{l}\text { Isoprenoid } \\
\text { flavonoids }\end{array}$ \\
\hline $\begin{array}{l}\text { Anti } \\
\text { inflammatory } \\
\text { diseases }\end{array}$ & \multicolumn{3}{|l}{} \\
\hline $\begin{array}{l}\text { Anti- } \\
\text { inflammatory }\end{array}$ & Fruit & $\begin{array}{l}\text { Aqueous } \\
\text { extract }\end{array}$ & $\begin{array}{l}\text { Prenyl } \\
\text { Flavonoids }\end{array}$ \\
\hline $\begin{array}{l}\text { Wound } \\
\text { healing }\end{array}$ & Leaf & $\begin{array}{l}\text { Ethyl acetate } \\
\text { extract }\end{array}$ & Flavonoids \\
\hline Anti - diabetic & Leaf & Alcoholic \\
\hline
\end{tabular}

\begin{tabular}{|c|c|c|c|}
\hline \multicolumn{4}{|l|}{ Miscellaneous } \\
\hline Antioxidant & Fruit and seed & $\begin{array}{l}\text { Alcoholic } \\
\text { extract and } \\
\text { aqeous }\end{array}$ & $\begin{array}{l}\text { Prenyl } \\
\text { Flavonoids }\end{array}$ \\
\hline Anti - malarial & $\begin{array}{l}\text { Bark if root and } \\
\text { stem }\end{array}$ & $\begin{array}{l}\text { Aerial part } \\
\text { extract }\end{array}$ & $\begin{array}{l}\text { Prenylated } \\
\text { Flavones }\end{array}$ \\
\hline $\begin{array}{l}\text { Anti } \\
\text { diarrhoeal }\end{array}$ & $\begin{array}{l}\text { Bark if root and } \\
\text { stem }\end{array}$ & $\begin{array}{l}\text { A. integrifolia } \\
\text { extract }\end{array}$ & $\begin{array}{l}\text { Prenylated } \\
\text { Flavones }\end{array}$ \\
\hline $\begin{array}{l}\text { Anti- } \\
\text { carcinogenic }\end{array}$ & Leaf & $\begin{array}{l}\text { Alcoholic } \\
\text { extract }\end{array}$ & Flavonoids \\
\hline Anti-platelets & Root, Seed & $\begin{array}{l}\text { Alcoholic } \\
\text { extract }\end{array}$ & Flavonoids \\
\hline $\begin{array}{l}\text { Anti- } \\
\text { tubercular }\end{array}$ & Root, Stem & $\begin{array}{l}\text { Dichlorometh } \\
\text { ane extract }\end{array}$ & $\begin{array}{l}\text { Prenylated } \\
\text { Flavones }\end{array}$ \\
\hline $\begin{array}{l}\text { Anti- } \\
\text { atherosclerosis }\end{array}$ & Fruit, root & $\begin{array}{l}\text { Ethyl acetate } \\
\text { extract }\end{array}$ & Flavonoids \\
\hline Anti - arthritic & Leaf, fruit & $\begin{array}{l}\text { Ethyl acetate } \\
\text { extract }\end{array}$ & Flavonoids \\
\hline
\end{tabular}

Table 3. Pharmacological activities of A. heterophyllus [Tejpal et.al., 2016]

The jackfruit seed flour starch is high in amylose, and hence can be used as thickening and binding agent in food industry. Galactomannan is one of the important polysaccharide found in seeds is extracted with greater efficiency using 50\% ethanol [12]. The seeds are known to function as good diuretics and extensively used in the ayurvedic medicine. They help in controlling hypertension by increasing the excretion of sodium along with water and decreasing the reabsorption of anions usually chloride. The seed extract shows remarkable antiinflammatory activity against carageenan induced inflammation.

A. heterophyllus latex has high content of phenols and tannins in methanolic, ethanolic and chloroform extract [11]. Latex finds application in clotting, wound healing and possess antimicrobial activity [13]. Latex is a good source of glycosides, tannins and proteins [14]. The leaf ethanolic extract is a good source of antimicrobial agents [15].

\section{Artocarpus hirsutus}

Artocarpus hirsutus commonly known as Wild jack. It is a folk medicinal plant used for treating ulcers, wounds, joint pains, etc. It is a large evergreen tree, growing up to $70 \mathrm{~m}$ height, grey coloured bark, branches are strigose with tawny hairs, leaves are upto $25 \times 14 \mathrm{~cm}$ broadly ovate, obovate or 


\section{Indo Global Journal of Pharmaceutical Sciences, 2020; 10(3): 48-55}

elliptic. A. hirsutus fruits are used in traditional medicine for curing skin diseases like abscesses, hydrocele, pimples, heal sores and skin cracks [16]. The decoction of A. hirsutus bark and roots is known to cure diarrhea and powdered bark heals sores. Leaves are used in treating buboes and hydrocele [17].

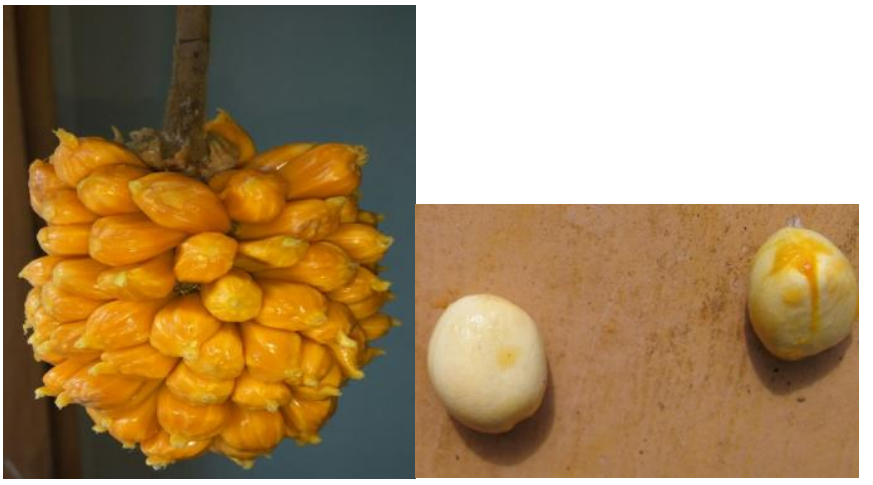

Figure 2. Fruit of $\boldsymbol{A}$. hirsutus (commons wikimedia.org)

The seed kernel of A. hirsutus appears as dark brown to sandy color in seed powder and the seed oil is dark yellow with characteristic sweet in odor while seed kernel and powder is bitter in taste. A. hirsutus seed oil contains a specific activity of 0.9471 , an acid value of 1.09 , saponification value 171.1 iodine value 103.26, peroxide value of 6.76 and an unsaponifiable matter of $5.83 \%$.

The oil extracted from wild jack seeds heals wound in humans and animals. The seeds are roasted and consumed as snacks by tribal people. Diverse endophytes were isolated from the barks releasing bioactive molecules which are potent antioxidant, anticancer, antimicrobial agents [18]. The silver nano-particles synthesized with leaf extract of wild jack showed good antimicrobial activity [19]. The protein content in the different Artocarpus sp was studied. A higher level of protein was noted in A. hirsutus, followed by A. heterophyllus, A. integer and $A$. incises [20]. The protein profiling by SDS-PAGE revealed 12 similar protein bands in seeds of these species with a molecular weight ranging from $61 \mathrm{kD}$ to $11 \mathrm{kD}$. These proteins were attributed with functions in storage, structure, cell recognition, enzyme inhibition and biological activity [21].The roots of $A$. hirsutus contains secondary metabolites like stigmasterol, lupeol, cyclomorusin, cycloartomunin and betulic acid [22]. The root extract showed potent anti-bacterial and anti-fungal activity [23]. Unripe fruit acts as astringent and ripe fruit functions as appetizer, coolant, aphrodisiac, and in ayurvedic treatment.

\section{Artocarpus lakoocha}

Artocarpus lakoocha is commonly called as Monkey jackfruit in some of the Asian countries such as Bangladesh, Bhutan, Nepal, Myanmar, Malaysia and Singapore [24]. They are rich sources of strong antioxidants like phenolics and flavonoids. The leaves of the plant constitute $16 \%$ of crude protein, used as food and timber [25]. Leaves are used as neonatal animal feed. The Monkey jackfruit is known to function as a liver refresher and possess various pharmacological activities like anti- inflammatory, anti-viral, anti-cancer and anti-HIV properties. The bark is used in wound healing and to cure abscess. Different metabolites from fruit such as cycloartenone, cycloartenol $\alpha$-amyrin and leupeol acetate were isolated [26]. Agglutinin lectin has been isolated from the seeds of lakoocha and function as a purgative and heamagglutinating agent. The heartwood contains phytochemical constituents such as cartocarpin, norartocarpin, norcycloartocarpin, cycloartocarpin, resorcinol, oxyresveratrol and $\beta$ - sitosterol [27]. Oxyresveratrol is a neuroprotective compound found in the plant also has antioxidant and antiinflammatory, anti-helminthic, anti-herpetic properties antiHIV and HSV and anti-glycation activity [28]. The preliminary phytochemical analysis of methanol extract of $A$. lakoocha fruit pericarp revealed the presence of tannins [29, 30] and alkaloids responsible for the anti-helmintic effect. Tannins are found to be useful in treating skin lesions. Tannins bind to free proteins in the gastrointestinal tract of host animal or glycoprotein on the cuticle of the parasite and may cause death thus showing anti-helmintic activity [31]. Monkey jackfruit extracts are used in cosmetics for skin whitening [32].In addition to oxyresveratrol, resveratrol and traces of some flavonoids were reported in the heartwood of this plant [33]. A. lakoocha fresh young leaf and fruit pulp extract is used to synthesize gold nanoparticles[34].

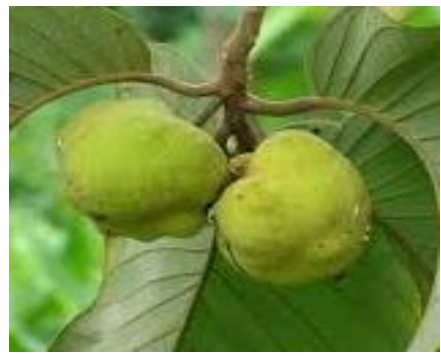

Figure 3. Fruit of A. lakoocha (projectnoah.com)

\section{Artocarpus camansi}

Artocarpus camansi is commonly known as breadnut and is considered to be a form of seeded breadfruit that is A. altilis (bread fruit). A. camansi is found in Indonesia, New Guinea and Philippines. The mature trees yield 600 to 800 fruits. The seeds are high in protein with low fat content. The seeds are good source of vitamins, minerals, unsaturated fatty acids like oleic acid, linoleic acid and arachidonic acid. Some of the minerals found in the seeds are sodium, potassium, calcium, magnesium, manganese and copper. They are also rich in amino acids leucine and phenylalanine $[35,36]$. A. camansi seeds contain fatty acid composition of oleic acid $12.4 \%$, stearic acid $2 \%$, lauric acid $1.7 \%$, palmitic acid $21.4 \%$, 
Indo Global Journal of Pharmaceutical Sciences, 2020; 10(3): 48-55

linolenic acid $14.8 \%$ and $1.9 \%$ arachidonic acid [36]. Organic acid such as butyric acid $(0.012 \pm 0.12)$, citric acid $(0.185 \pm 0.32)$, acetic acid $(0.050 \pm 0.48)$, malic acid $(0.012 \pm 0.17)$, lactic acid $(0.317 \pm 0.51)$ (in $\mathrm{mg} / \mathrm{kg}$ ) are found in the seeds [36].

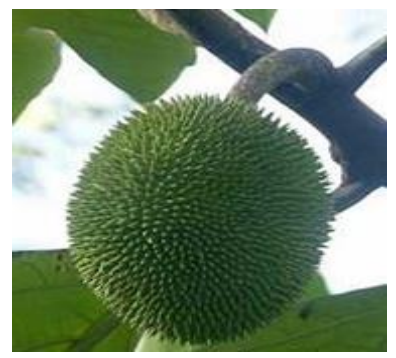

Figure 4. A. camansi (toptropicals.com)

\begin{tabular}{|l|l|}
\hline $\begin{array}{c}\text { Amino acid composition } \\
\text { (mg/g N) }\end{array}$ & \multicolumn{1}{c|}{ Breadnut seeds } \\
\hline Arginine & 293 \\
\hline Histidine & 167 \\
\hline Isoleucine & 245 \\
\hline Leucine & 392 \\
\hline Lysine & 275 \\
\hline Phenylalanine & 312 \\
\hline Tyrosine & 185 \\
\hline Cystine & 112 \\
\hline Tryptophan & 24 \\
\hline Methionine & 95 \\
\hline
\end{tabular}

Table 4. Amino acid composition of $A$. camansi seeds [Adeleke et. al., 2010]

\section{Artocarpus altilis}

Artocarpus altilisis also known as A. communis, A. incises and commonly called as bread fruit. It is native to Indonesia, Guinea and Philippines. The fruit is a rich source of carbohydrate with low fat and it is considered as starch rich crop. Fruits can be with seeds and without seeds. Leaves are found to be a rich source of steroids, phytosterols, gums and resins. Secondary metabolites such as arylbenzofurons, flavonoids and stilbenoids do occur. Fruits are a good source of many chemical constituents such as morin, moracin, dihydromorin, cynomacurin, oxydihydroartocarpesin, articarpetin, norartocarpetin, cycloartinone, cyclogeracommunin, cyclocommunol, cycloartenyl acetate, $\beta$ sitosterol, ursolic acid, betullic acid acetate, artoflavon, cudraflavone, artocarpanone, oxyresveratrol and orartocarpanone [37].

The plant has many pharmacological uses, such as antiinflammatory, anti-fungal, anti-diabetic, anti-bacterial, anticholinergic and antioxidant activity. The leaf extracts show toxicity towards cancer cells, and anti-helminthic activity. The extracts also act as cosmetic whitening agents. Root extract possess anti-coagulant activity. The latex of the plant is used in treating diarrhea [38], dysentery, indigestions [39] and menorrhagia [40]. The leaves are crushed and used for treating skin ailments, ear infections[39], to treat fever, hypertension [41], liver disease [39], oral inflammation and pain [42],fresh leaf buds [40] and leaf buds along with coconut oil are used in ciguatera poisoning [43].The male inflorescence is used as a mosquito repellant [38]. The plant contains phytochemicals such as 2-geranyl-2'-3,4,4 hydroxy dihydro chalcone which inhibits 5- $\alpha$ reductase [44], Artochamins-B, Artochamins-D, dihydroartomunaxanthone [45], Artonon-E and KB-2 [46]. Frutackin is a compound extracted from seeds of breadfruit is known to possess anti-fungal property [47]. Morusin possess anti-tumor property and they are found in the stem bark. Moracin M from fruit is antioxidant, anti-fungal, cytotoxic and phytotoxic. Oxyresveratrol from fruit extract is an antioxidant and anti-fungal agent [48]. A. altilis leaf extracts are used to synthesize anti-bacterial and antioxidant silver nano-particles [49].

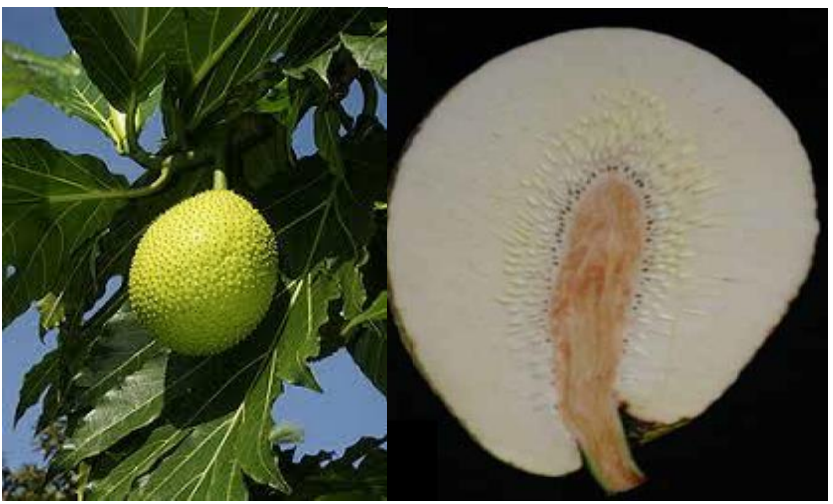

Figure 5. A. altilis (en.wikipedia.org)

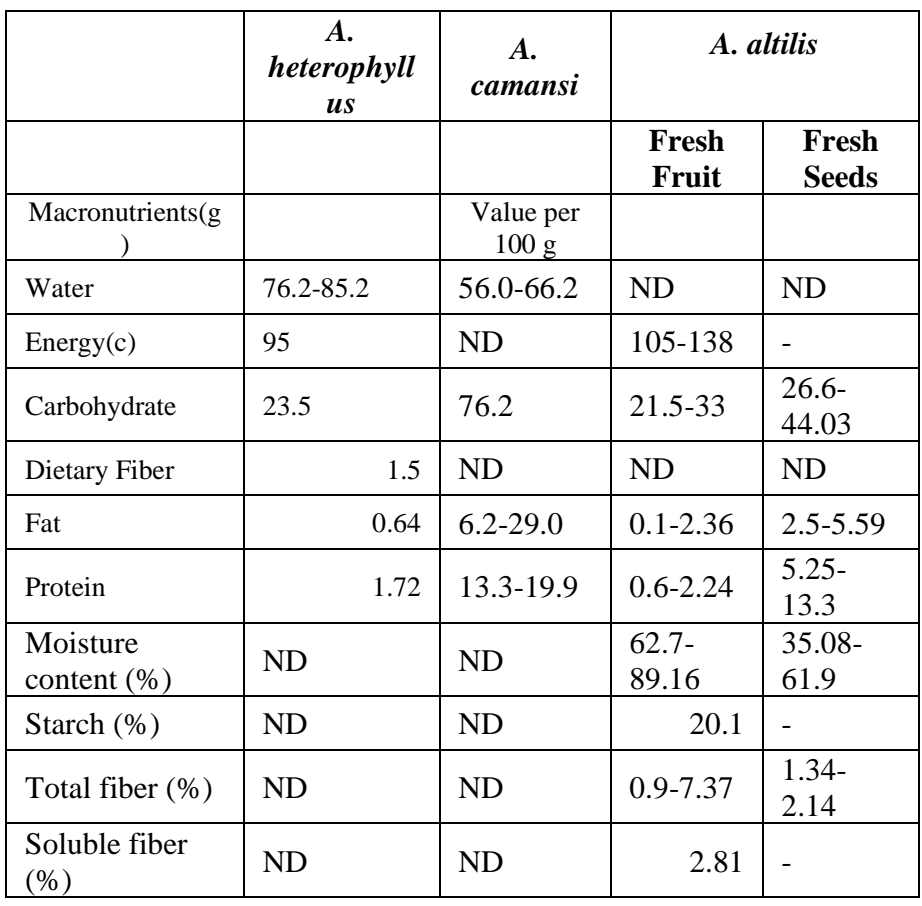


Indo Global Journal of Pharmaceutical Sciences, 2020; 10(3): 48-55

\begin{tabular}{|c|c|c|c|c|}
\hline Ash (\%) & ND & ND & $0.56-1.2$ & $\begin{array}{l}1.5- \\
5.58\end{array}$ \\
\hline $\begin{array}{l}\text { Copper } \\
(\mathrm{mg} / 100 \mathrm{~g})\end{array}$ & ND & ND & 0.08 & - \\
\hline $\begin{array}{l}\text { Boron } \\
(\mathrm{mg} / 100 \mathrm{~g})\end{array}$ & ND & ND & 0.52 & - \\
\hline $\begin{array}{l}\text { Retinol } \\
\text { equivalents }\end{array}$ & ND & ND & 15.2 & - \\
\hline Sugar & 19.08 & ND & 2.9 & - \\
\hline $\begin{array}{l}\text { Micronutrients(m } \\
\mathrm{g})\end{array}$ & In mg & & & \\
\hline Calcium & 34 & $66-70$ & $0.05-30$ & $\begin{array}{l}0.11- \\
49.3 \\
\end{array}$ \\
\hline Iron & 0.6 & 8.7 & $0.29-2.4$ & $2.3-3.87$ \\
\hline Magnesium & 37 & 10 & $20-34$ & ND \\
\hline Manganese & 0.197 & ND & ND & ND \\
\hline Phosphorous & 36 & $320-360$ & 0.04-79 & $0.35-189$ \\
\hline Potassium & 303 & $380-1620$ & $283-480$ & - \\
\hline Sodium & 3.3 & 1.6 & $1.0-70$ & ND \\
\hline Zinc & 0.42 & ND & $\begin{array}{l}0.07- \\
0.12 \\
\end{array}$ & - \\
\hline Vitamins (mg) & & ND & ND & ND \\
\hline Folate $(\mu \mathrm{g})$ & 24 & ND & ND & ND \\
\hline Niacin & 0.92 & 8.3 & $0.75-1.4$ & - \\
\hline Pyridoxine & 0.329 & ND & ND & ND \\
\hline Riboflavin & 0.055 & ND & $\begin{array}{l}0.02- \\
0.05 \\
\end{array}$ & - \\
\hline Thiamine & 0.105 & ND & $\begin{array}{l}0.09- \\
0.15\end{array}$ & - \\
\hline Vitamin A (IU) & 110 & ND & ND & ND \\
\hline Vitamin C & 13.7 & ND & $1.6-34.4$ & $1.9-22.6$ \\
\hline Vitamin E & 0.34 & ND & ND & ND \\
\hline \multicolumn{5}{|l|}{ Phytonutrients $(\mu \mathrm{g})$} \\
\hline Carotene- $\beta$ & 61 & ND & 19.6 & - \\
\hline Crypto-xanthin- $\beta$ & 5 & ND & ND & ND \\
\hline $\begin{array}{l}\text { Lutein- } \\
\text { zeaxanthin }\end{array}$ & 157 & ND & $\begin{array}{l}38.6- \\
119.7\end{array}$ & - \\
\hline
\end{tabular}

Table 5. Phytochemistry of A. heterophyllus [Tejpal et. al., 2016], A. camansi per 100 grams. [Ragone, 2006], A. altilis [Jones et.al., 2011] [51]

\section{APPLICATIONS}

The present review discusses about the importance and significance of Artocarpus species. The seeds and fruits of Artocarpus are rich in vitamins, minerals, phenols, flavanoids and antioxidants. Various value-added products are available from the seeds of these plants, which are good source of instant energy. The extracts of these plants exhibits remarkable benefits such as anti-bacterial, anti-fungal, antidiarrhoeal, anti-tyrosinase, anti-inflammatory and anti-diabetic activities. Some species are used in the treatment of tapeworm

infection. They have wide applications in cosmetics as skin whitening agents. The flavones and flavanoids present in Artocarpus contribute for the anti- cancer activity and can be developed as good chemotherapeutic agents.

Lectin, a protein isolated from the seeds of Artocarpus is good hemagglutinating agents, and can be used as a therapeutic ailment for the treatment of HIV infection. Thus they have got a wide application in the field of biochemistry.

\section{CONCLUSION}

The review presents the biological activities and the phytoconstituents in the commonly found Artocarpus members of India. They are rich resources of substances with antioxidant, anti - inflammatory, anti - helminthic, anti diabetic, anti - analgesic, anti - herpetic, anti - HSV, anti HIV and anti - cancerous activities. In case of A. lakoocha agglutinin lectin functions as a purgative and heamagglutinating agent. A. heterophyllus lectins like Jacalin is a promising material in nanomedicine. Artocarpus species, especially altilis is potent resource of various chemotherapeutic agent involved in control of growth of cancerous cells. A. altilis finds cosmetic applications since they possess tyrosinase inhibitory activity. A. communis extracts inhibits 5- lipoxygenase activity and a compound extracted from A. incisus inhibits $\alpha$ - reductase activity. Thus, Artocarpus members will be a resource of substances with various therapeutic properties. In the future they could be contributing safe phytochemicals and enhance the quality of health in generations to come.

\section{ACKNOWLEDGEMENT}

Department of Biochemistry, Bangalore University, Bangalore and INSPIRE Fellowship from DST, New Delhi, India is gratefully acknowledged.

\section{SUPPLEMENTARY DATA}

Supplementary data is available at below link:

Supplementary file.

\section{DATA AVAILABILITY}

Not declared.

\section{CONFLICTS OF INTEREST}

Nil

\section{FUNDING SOURCE}

No external funding declared. INSPIRE Fellowship from DST, New Delhi, India is gratefully acknowledged. 


\section{Indo Global Journal of Pharmaceutical Sciences, 2020; 10(3): 48-55}

\section{REFERENCES}

1. Sang, K.E., Zhou, Z., Gilbert, M.G. Moraceae, Flora of China., 2003; 5: 21-73.

2. Gerald, C. Moraceae - Flowering Plant Families. University of Hawaii. Botany Department., 2006; available at http://www.botany.hawaii.edu/faculty/carr/mor.htm.

3. Roy, S.K., Royand, P.K., Brumfield, R.G. In vitro propagation and establishment of a new cultivar of jackfruit (Artocarpus heterophyllus Lam.) bearing fruits twice yearly, Acta Hortic., 1996; 429: 497-502.

4. Pradeep Kumar $\mathrm{T}$ and Kumar, P. Management of horticultural crops. Horticulture Science Series, New India Publishing agency: India, 2008; 81- 84

5. Jain ,A.P., Tote, M.V., Mahire, N.B., Undale, V.R., Bhosal, V.R. Evaluation of Anticonvulsant activity of methanolic extract of Artocarpus heterophyllus Lam. (Moraceae) in mice. J. Pharm Res., 2009; 2: 1004-1007.

6. Samaddar, H.M. Jackfruit. InT.K. Bose and S. K. Mishra (Eds.), Fruits of India: Tropical and subtropical. Culcutta, India, 1985; 638-649.

7. Jagtap, U.B and Bapat, V.A. Artocarpus: A review of its traditional use, phytochemistry and pharmacology, J. Ethnopharmacol., 2010; 129: 142-166.

8. Singh, A., Kumar, S., Singh, I. S. Functional Properties of jackfruit seed flour. LWT., 1991; 24: 373-374.

9. Prakash, O., Mishra, A., Gupta, R. Artocarpus heterophyllus (Jackfruit): An overview. Pharmacogn Rev., 2009; 3: 353-358.

10. Bhat, V., Mutha, A., Dsouza, MR. Pharmacognostic and Physiochemical studies of Artocarpus heterophyllus seeds. IJCRGG., 2017; 10; 525-536.

11. Nair, S.S., Nithyakala, C. M., Noronha, I. G., Sultana, N., Someshekharaiah, B.V. Isolation and determination of nutritional and anti-nutritional compounds from the seeds of selected plant species. JCPR., 2012; 4: 3529-3534.

12. Dasaesamoh, R and Seechamnanturkit, V. Extraction and enzymatic depolymerization of gum from Artocarpus heterophyllus Lam. seeds. IFRJ., 2014; 21: 2245-2251.

13. Madhavi, Y., Rao, R.K.V., Kiran, R.C.H., Rao, R.T., Studies on phytochemical analysis and antimicrobial activity of Artocarpus heterophyllus fruit latex against selected pathogenic microorganisms. IJSER., 2013; 4: 1458-1468.

14. Tejpal, A and Amrita, P. Jackfruit: A health Boon. Review article. IJRAP., 2016; 7: 59-64.

15. Sivagnanasundaram, $\mathrm{P}$ and Karunanayake, K.O.L.C. Phytochemical Screening and Antimicrobial activity of Artocarpus heterophyllus and A. altilis Leaf and Stem Bark extracts. OUSL. 2015; 9:1-17.

16. Hebbar, A.S., Chaithra, S., Ravikrishna., Suchitra, P.N. Pharmacognostical and analytical analysis of Artocarpus hirsutus Lam. - A folk plant. IAMJ., 2017; 5: 411-417.

17. Nayak, M., Nagarajan, A., Majeed, M. Pharmacognostic evauation of leaf and stem wood extracts of Artocarpus hirsutus Lam. J. Pharmacogn., 2017; 9: 887-894.

18. Ruma , K., Shailasree, S., Sampath, K.K.K. Diversity of Fungal Endophytes Tree Species Artocarpus hirsutus Lam. And Vateriaindica Linn. Of Western Ghats, India. IDOSI Publications. WJAS., 2011; 7: 577-582.

19. Anu, V., Methi, R.S., Mujeeb, C.A., Vinod, M.K. Biosynthesis of silver nanoparticles from Artocarpus hirsutus leaf extracts its anti-microbial activity and phytochemical analysis. IJRPNS., 2015; 4: 28-39.

20. Sirisha, N.K., Rao, R.V., Rao, B., Rao, R.T. Evaluation of antioxidant activities, phytochemical constituents and protein profiling of five varieties of Jackfruit (Artocarpus species) seeds. IJPSR., 2014; 4: 626-631.

21. Fukusima, D. Recent progress of soybean protein foods: Chemistry, technology and nutrition. Food Rev Int., 1991; 7: $323-$ 351.

22. Pethakamsetty, L., Ganapathy, S., Bharathi, M.K. Phytochemical and Biological Examination of the root extract of Artocarpus hirsute Lam. IJOBIO., 2013; 2: 735-738.

23. Suvarna, V.M.N., Ramesh, B.S., Venkatachalapathy, R., Makari Hanumanthappa, K, Ramaganesh, C.K., Karunakar, B.S.. Evaluation of antioxidant activity of Artocarpus hirsutus methanolic fruit extract: An invitro study. IJSR., 2013; 2: 12.

24. Hossain, M.F., Isla, M.A., Akhtar ,S. , Numan, S.M.. Nutritional value and medicinal uses of Monkey Jackfruit (Artocarpus lakoocha). IJRBS., 2016; 5: 60-63.

25. Dorthe Joker. Artocarpus lakoocha Roxb. Seed Leaflet. DFSC and Bharat Adhikari TISC., 2003; 73.

26. Pandey, A. and Bhatnagar, SP. Antioxidant and Phenolic content of the bark of Artocarpus lakoocha. The Pharma Rev. KongPosh publications., 2009; 1: 23-28.

27. Gautam, P and Patel, A. Artocarpus Lakoocha Roxb: An Overview. EJCAM., 2014;1:10-14.

28. Maneechai ,S., Likhitwitayawuid, K., Sritularak, B., Palanuvej, C., Ruangrungsi, N., Sirisaard ,P. Quantitative analysis ofoxyresveratrol content in Artocarpus lakoocha and Puag-Haad. Med Princ. Pract., 2009; 18: 223-227.

29. Pandey, A and Bhatnagar, SP. Preliminary screening and anti microbial studies on Artocarpus lakoocha Roxb. Anc Sci Life., 2009; 28: 21- 24.

30. Kumar, S.M.B et. al. Screening of selected biological activities ofArtocarpus lakoocha Roxb (Moraceae) fruit pericarp. J Basic Clin Pharm., 2010; 1: 239-45.

31. Athnasiadou, S., Kyriazakis, F., Jackson, R.L. Direct anti helmintic effects of conden sed tannins towards different gastrointestinal nematodes of sheep: In vivo studies. Vet Para sitol., 2001; 99: 205-219.

32. Tengamnuay, P., Pengrungruangwong, K., Pheansril., Likhitwitayawuid, K. Artocarpus lakoocha heart-wood extract as a novel cosmetic ingredient:evaluation of the in vitro anti-tyrosinase and invivo skin whitening activities, Int $\mathrm{J}$ of Cosme Sci., 2006; 28: 233-241.

33. Venkataraman, K. Wood phenolics in the Chemotaxonomy of the Moraceae. Phytochem., 1972; 11: 15711586 .

34. Baruah, D., Das, R.M., Hazarika, S., Konwara, D. Biogenic synthesis of cellulose supported Pd (0) nanoparticle using hearth wood extract of Artocarpuslakoocha Roxb - A green, efficient and versatile catalyst for Suzuki and Heck coupling in water under microwave heating. Catal. Commun. 2015; 72: 73-80

35. Adeleke, R. O. and Abiodun, O.A. Nutritional composition of breadnut seeds (Artocarpus camansi). AJAR., 2010; 5: 1273-1276.

36. Ragone D. Artocarpus camansi (breadnut). Species Profiles for Pacific Island Agroforestry., 2006

37. Pradhan, C., Mohanty, M., Rouf, A. Phytochemical screening and comparative bioefficacy assessment of Artocarpus altilis leaf extracts for antimicrobial activity. Front Life Sci. 2012;67:1-76.

38. Navarro ,M., Malres, S., Labouisse, J.P., Roupsard, O. Vanuatu breadfruit project: Survey on botanical diversity and traditional usesof Artocarpus altilis:In Proceedings of the 1st International Symposium on BreadfruitResearch and Development. Acta Hortic., 2007; 757: 81-88.

39. Zerega, N.J.C., Ragone, D., Motley, T.J. Systematics and species limits of Breadfruit (Artocarpus, Moraceae). American 
Indo Global Journal of Pharmaceutical Sciences, 2020; 10(3): 48-55

Society of Plant Taxonomists.Syst Botany., 2005;30: 603- 615. http://www.researchgate.net/publicatio n/238502215.

40. Bourdy, G., Walter, A. Maternity and medicinal plants in Vanuatu-The cycle of reproduction. J Ethnopharmacol., 1992;37: 179-196.

41. Lans, C.A. Ethno medicines used in Trinidad and Tobago for urinary problems and diabetes mellitus. J Ethnobiol Ethnomed. 2006; 2: 45-56.

42. McClatchy, W.C. The traditional Rotuman Medicinal System and Ethanopharmacopoea, Brigham Young University, Provo,Utah., 1993

43. Lobel, P. Folk remedies for tropical fish poisoning in the Pacific. Sea Frontiers. 1979;25:239-245

44. Shimizu, K., Kondo, R., Sakai, K., Dilokkunanant, U. A geranylated chalcone with $5 \alpha$ - reductase inhibitory properties from Artocarpus incises, Phytochem., 2000;54: 737-739.

45. Wang Y., Kedi, Zheng L. Geranyl flavonoids from the leaves of Artocarpus altilis. Phytochem., 2007; 68: 1300-1306.

46. Nomura, T., Hano, Y., Aida, M. IsoprenoidsubstitutedFlavonoids from Artocarpus plants (Moraceae), International Journal for Reviews and Chemistry. ,1998; 2: 1179 1205.

47. Nilupa, R., Amarasinghe., Jayasinghe,L., Hara, N.,Fujimoto, Y. Chemical constituents of the fruits of Artocarpus altilis. Biochem Systs and Ecol., 2008; 323-325.

48. Trindade, M.B., et. al. Structural characterization of novel chitin-binding lectins from the genus Artocarpus and their antifungal activity. Biochem Biophys Acta., 2006; 1764: 146-152.

49. Ravichandran, V., Vasanthi, S., Shalini,S., Rajak, H. Green synthesis of silver nanoparticles using Artocarpus altilis leaf extract and the study of their anti- microbial and anti- oxidant activity. IJPLS., 2016; 180: 264-267.

50. Ocloo, F.C.K., Bansa, D., Boatin, R., Adom, T., Agbemavor, WS. Physico- chemical, functional and pasting characteristics of flour produced from jackfruits (A. heterophyllus seeds). Agric. Biol. J. N. Am., 2010; 1: 903-908.

51. Jones, A.M.P., Ragone, D., Tavana, N.G., Bernotas, D.W., Murch, S.J. Beyond the Botany: Breadfruit (Artocarpus altilis) for food security and novel foods in the 21 st century. EBRA .University of Hawaii at Manoa., 2011; 9: 129-149.

Indo Global Journal of Pharmaceutical Sciences( ISSN 2249 1023; CODEN- IGJPAI; NLM ID: 101610675) indexed and abstracted in CrossRef (DOI Enabling), CNKI, UGC CARE Journal List, EMBASE (Elsevier), National Library of Medicine (NLM) Catalog (NCBI), ResearchGate, Publons (Clarivate Analytics), CAS (ACS), Index Copernicus, Google Scholar and many more. For further details, visit http://iglobaljournal.com 